DOI: 10.19195/0137-1150.163.53

\author{
IGOR FIC \\ Univerzita Palackého v Olomouci, Republika Czeska \\ igorfic@centrum.cz
}

\title{
Motivy stáŕí a smrti v pozdním díle Violy Fischerové
}

Stáří je bezpodmínečně spojeno se smrtí. Jinak si je ani neumíme představit. Smrt není jen cílem lidského života, smrt, stejně jako život, je jeho antropologickou konstantou. $\mathrm{O}$ smrti nelze mluvit bez života. $\mathrm{O}$ životě nelze hovořit bez smrti. O smrti nelze říct nic, pokud ji neprožijeme. Avšak pokud ji prožijeme, pak je tato zkušenost nesdělitelná, nepřenosná. Za našeho života nahlížíme smrt vždy zvnějšku. Proto jsou pro nás důležité rituály spojené se smrtí, proto jsou pro nás důležité dějiny smrti. ${ }^{1}$ Každý z nás je se smrtí často konfrontován, každý z nás o smrti často hovoří. A není významnějšího uměleckého díla, v němž by nebyla přítomna smrt. Pravda, jsou taková díla, která k smrti př́mo, odkazují, kdy je smrt hlavním tématem uměleckého vyjádření. ${ }^{2}$ Ale též za většinou uměleckých ztvárnění života stojí smrt v podobě prchavosti okamžiku, v podobě vzpomínky uložené do paměti. Ale pamět' je proměnlivá a s časem jí ubývá. Každý život se odvíjí v čase, každý život je časem hnán ke smrti. Co víc, každý z nás v sobě nese vlastní smrt. Smrt souvisí s individuálním životem, ovšem lidský život, stejně jako kultura a umění, reprezentují smrt. ${ }^{3}$

Toto téma pojednal ne filozoficky, ale především vědecky, Thomas Macho. Ve studii, která byla připojena ke krátké monografii Jana Assmanna s názvem Smrt jako fenomén kulturní teorie, se zabývá právě nemožností nahlédnout smrt

${ }^{1}$ Srov. P. Ariés, Dějiny smrti (L'homme devant la mort, 1977), přel. D. Navrátilová, Praha 2000.

${ }^{2}$ Srov. A. Corvisier, Tance smrti (Les danses macabres, 1999), přel. L. Kolářová, Praha 2002.

${ }^{3}$ Srov. D.J. Davies, Stručné dějiny smrti (A Brief History of Death, 2005), přel. M.F. Havrdová, Praha 2007. 
zevnitr. ${ }^{4}$ Zmíněný problém rozebírá $\mathrm{v}$ rámci „metodologické poznámky”, kterou klade na úvod vlastní stati. Jako exaktní vědec si je velmi dobře vědom, že otázky mystické zkušenosti smrti musí oddělit od vlastního předmětu bádání, jímž je analýza obrazů a rituálů smrti, zkoumání pohřebních obřadů, nahlížení na cesty zemřelého podle kulturologických a antropologických vzorců. Thomas Macho proto zdůrazňuje omezenost hranice poznání v oblasti vědeckého pohledu na umírání a smrt:

Zatímco většina předmětů kulturněhistorického bádání — od „rites de passage” (narození, sexualita, nemoc) až po technické a hmotné objektivizace každé kultury — klade teoretické analýze jen poměrně malý odpor, zůstává smrt zcela neprůhledným a neproniknutelným fenoménem. Smrt je známa pouze zvnějšku, neumožňuje žádné „hermeneutické” přiblížení ani „zúčastněné pozorování”. Smrt nelze konstituovat jakožto předmět poznání bez ohledu na další okolnosti: tato věta tvoří přímo nutně negativní axiom každé vědecké thanatologie. Tuto negativní axiomatiku je možné ožrejmit odkazem na další obtíže. Smrt samotná postrádá mentální reprezentaci. Každá představa smrti — bez ohledu na to, zda se jedná o smrt jiného člověka, nebo o budoucí vlastní smrt — naráží na elementární logický problém, že žádný systém si nedokáže bezrozporně představit svůj vlastní konec. ${ }^{5}$

Tato metodologie se vymezuje vůči vlastnímu předmětu zkoumání, přestože jej vnímá a akceptuje v nejrůznějších projevech a formálních obměnách. Žádný systém, jehož předmětem je zkoumání smrti a boží existence, „si nedokáže bezrozporně představit svůj konec." Jenže znázornění smrti, podobně jako znázornění Boha (v podobě boží trojice), je možné a svůj teoretický podklad nachází v principu paradoxu, v tom, co Thomas Macho označuje jako rozporný prvek systému. Stačí připomenout, že II nicejský koncil (787 n.l.) vyjádřil dogma o soupodstatnosti tř́ božských veličin jako iracionální a neuchopitelné, což právě činilo potíže při znázornění Boha, ale zároveň uznal uctívání obrazů a znázornění Boha jakožto vzorové, typické, následováníhodné. Ovšem už předtím Dionýsios Areopagita, ${ }^{6}$ známý též jako Pseudo-Dionýsios, tvrdí, že Boha lze vyjádřit pouze negativně, tedy prostřednictvím toho, co není. Jeho závěry v různých obměnách $\mathrm{s}$ větší či menší mírou platnosti poskytují teoretické základy pro vyjádření Boha především v umění, které se $\mathrm{v}$ mnoha ohledech, daleko spíš jak věda, názorně dotýká nadčasových hodnot. Takže pokud v oblasti interpretace a analýzy uměleckého díla nahlédneme Machovu metodologii z jiného úhlu pohledu a při vědomí širších teoretických východisek, můžeme snadno vytvořit premisu: smrt je branou do věčnosti, což nutně vytváŕí pozitivní axiom každé eschatologie.

${ }^{4}$ J. Assmann, Smrt jako fenomén kulturni teorie. Obrazy smrti a zádušní kult ve starověkém Egyptě (Der Tod als Thema der Kulturtheorie. Todesbilder und Totenriten im Alten Ägypten, 2000), přel. R. Fialová, Praha 2003.

5 T. Macho, Smrt a truchlení v kulturologické perspektivě, přel. R. Fialová, [w:] J. Assmann, Smrt jako fenomén kulturni teorie. Obrazy smrti a zádušní kult ve starověkém Egyptě, Praha 2003, s. 71.

${ }^{6}$ Srov. Sv. Dionýsios Areopagita, O mystické teologii, O božských jménech (Мистическое богословие восточной церкви, 2001), přel. A. Černohous, Praha 2003. 
Smrt je spojena s filozofickými či teologickými pojmy jako je absolutno, nicota, věčnost a podobně. Německý filozof Paul Ludwig Landsberg v knize Zkušenost smrti rríká: „Dokonale může člověk nabýt podílu na věčnosti božské osoby teprve na druhé straně smrti a takovým způsobem, že se smrt stává zrozením, ve vyšším a pravém smyslu, než je zrození empirické. Je-li tu život, který je v pravdě smrtí, je tu také smrt, která je vpravdě životem.." Podle Landsberga však člověk nemusí zemřít, aby prožil bezprostřední vnitřní zkušenost smrti. Jedná se o implicitní zkušenost smrti. „Zkušenost Boha, které se dostává mysticky nadaným duchům, zahrnuje vždy také jim vlastní zkušenost smrti. Tito mystikové nestojí sami o sobě nad ostatními věŕícími, právě tak jako nejsou jen paradoxními a trapnými výjimkami náboženského života." 8

Právě v oblasti náboženského života, jenž zcela jasně zahrnuje i kulturologická, antropologická a kunsthistorická zkoumání, známé texty označované jako ars moriendi, nebo ještě lépe jako ars bene moriendi. Umění dobré smrti? Z formálního hlediska plní podobnou úlohu jako „zpovědní zrcadla.” Každá forma či rituál, nebo př́klad, exemplum, vede k iniciaci a k personální identifikaci s předmětem, který znázorňují. Proto mohl Pavel Král ve studii s názvem Knihy o dobrém umirání napsat větu: „, okamžiku, kdy se takovéto normativní texty staly součástí každodenní praxe, je lze však vnímat i jako prostředek poznání zkušenosti smrti." ${ }^{9}$ Ovšem daleko víc jak půl století předtím ve studii Básník a jeho inspirační zdroje sdělil Jan Čep podstatné: „Třetím inspiračním zdrojem [...]básníka je to, čemu se ř́ká v křest’anské řeči communio sanctorum, obcování svatých, tj. vědomí o tajemném společenství živých a mrtvých, minulých i budoucích, kteří jsou svázáni poutem duchovního rodu, lásky i viny, vzájemné zásluhy a oběti." ${ }^{10}$ A v jeho známé eseji Dvojí domov čteme: „Není pochyby, že ve vytváření obrazu našeho pozemského domova, našeho rodného kraje, jsou účastny dvě věci: rozloučení a vzpomínka."11

Umění vykazuje jistá privilegia. Jedním z nich je setrvání ve skutečnosti, že ono samo je rituálem. Každý, kdo se na něm podílí, anebo je dotváŕí, obnovuje a zpř́tomňuje, se svým životem a smrtí dotýká věčnosti. Jedinečně, personálně. Pokud je v takovém př́ípadě hlavním tématem stáří a smrt, vzniká forma, která neopakovatelným způsobem supluje zaniklé artefakty označované jako ars bene moriendi. Básnické dílo Violy Fischerové je toho př́ikladem.

Vládne mu smrt. Smutek. Od počátku. A hledání, nezbytná míra ztišení, vnímavost $\mathrm{k}$ odloučení, jež s sebou nese jednu bezodkladnou otázku: jak v mém

${ }^{7}$ P.L. Landsberg, Zkušenost smrti (Essai sur l'expérience de la mort, 1936), přel. L. Hejdánek, J. Sokol, Praha 1990, s. 158.

${ }^{8}$ Ibidem, s. 159-169.

${ }^{9}$ P. Král, Knihy o dobrém umírání v českém prostředi ve druhé polovinè 16. a první půli 17. století, [w:] Církev a smrt. Institucionalizace smrti v raném novověku, eds. M. Holý, J. Mikulec, Praha 2007, s. 8.

10 J. Čep, Rozptýlené paprsky, Praha 1991, s. 30.

11 Ibidem, s. 13. 
životě zůstávají zemřelí, jak vidí oni mne? Tato otázka se objevuje ve všech básnířčiných sbírkách počínaje Zádušními básněmi za Pavla Buksu. ${ }^{12}$ Motivy smrti pak transparentně vyvstávají v knize s názvem Divoká dráha domovů. ${ }^{13}$ Není tu prostor pro zkoumání vztahu literárního díla s biografií Violy Fischerové, ale téma domovů, za nimiž se skrývají mrtví, se prolíná s myšlenkou na domov. Kniha je rozdělena do dvou částí.

V první se objevuje právě téma domova či domovů in concreto. Odkazuje k nim i datace: Praha-Augsburg-Elba-Praha 1993-94. Jejich vnímání je zpravidla spojeno s pocitem opouštění a ztráty, s tím, co sugeruje slovo hlubokého smyslu: návrat. A tak se význam slova „domov” neznatelně odpoutává od vazby na dům, ulici, zahradu, jabloň atd., opouští tyto důležité symboly a nabývá obecnějšího a širšího významu, jenž generuje celou řadu dalších otázek: je vůbec možné ztratit domov? Jaký? Ten co žije v našem srdci a v naší duši? Ten, který neseme s sebou? Ten, k němuž směřujeme, který je nám dán naší smrtí? A jaký domov mají naši mrtví?

$\mathrm{O}$ mrtvých je řeč především. Hned v úvodu jsou naznačeny dvě roviny možných úvah a pocitů: předně, mrtví jdou s námi, což je osvobozující a útěšné; a potom je tu fakt, že na takovou skutečnost často zapomínáme nebo o ní nechceme vědět. Knihou vládne především rovina první, druhá je tu více, tu méně kontrastním pozadím pro místa, kde se básnířka alespoň částečně vyvazuje z nutkavého sevření vyznáním — sdělením toho nejvýznamnějšího a neodsunutelného poznání: mrtví, stejně jako živí, tvoří domov.

Ten domov to nejsou jen „mé domovy”, kde jsem byla a kde bych chtěla být, ale především je to celistvost vnímání místa: zde žili a žijí lidé. Je to celistvost vnímání i uskutečňování lidských osudů, procházejících i prošlých lidských životů. Dotyk se zdmi promodlenými, vnímavost pro stopy utrpení i lásky, jež nezmizí.

Je to kniha o stáŕí. Stáří, jež zůstane až do smrti, stáŕí viděné, vědomé a přijímané. Je i pozorováním těch, kteří odcházejí, a počítání těch, kteří nás předešli. Stáří má mnoho podob, ale dvě hlavní: unikání života — hmatatelné a zjevné a naplnění života — přicházející a očekávatelné. A jsou tu konce života. Registrace všech dohledných a okamžitě dohlédnutelných konců života, tak, jako třeba ubití raněného holuba atd. Nebo potrat: doslova konec $\mathrm{v}$ začátku, smrt před životem, loučení před setkáním. Ďábelská dějová zkratka, protože život je umírání.

Druhá část knihy je trošku jiná. Víc obrazná, snad i expresivnější, méně subjektivní a niterně naléhavá, víc obecná, mnohdy až neosobní, reflektující stav věcí, důrazně klasifikující skutečnost až k hranici poučení. Místy imperativní. Méně konkrétní a vnímatelná jen v obrysech — infinitivně nepř́stupná. Charakter básnické výpovědi se změnil. Je jaksi lhostejnější a zatvrzelejší, nepodléhá pouhému uvykání si danému stavu věcí. Je to zkušenost, nikoli zvyk; věcnost

12 V. Fischerová, Zádušní básně za Pavla Buksu, Brno 1993.

${ }^{13}$ V. Fischerová, Divoká dráha domovů, Praha 1998. 
a popisnost, ne sentiment. Ortel znějící jasně a tvrdě, ale přece jen jakoby mimochodem. Implikuje větu: zmýlená neplatí. Fakticita soudu ukazuje spíš na neústupnou přesvědčivost.

A místo ubývání je tu zánik, místo umírání - smrt, místo vzpomínání prŕtomnost. Obrazy se střídají rychleji, jsou ted' a tady, expresivní vyjádření stř́ídá jemná imprese. Přesto $s$ námi jdou vždy a všude naši mrtví. I vzpomínání má mnoho podob. Jednou z nich je odevzdání.

Vzpomínání je stav mysli a stav srdce. Je to usebrání i přeříkávání prošlého života. A tenkrát jsme nevěděli, co nás čeká, stejně, jako to nevíme dnes. Vzpomínání je i znovuzískávání a především znovu tvoření toho, co se z paměti vytratilo, co však náleží jen nám. I tato kniha je vzpomínání, láska, smutek a stesk vstř́ic smrti. Už ne smrti obecně, jako ze začátku, ale smrti zcela konkrétní, žijící ve mně a v mých blízkých. Smrti, již vidím na vlastní oči, již cítím.

Podívejme se na verše: „temná oprýskaná ulice / kde chybějí i mrtví”"14, což se čte hned v první básni s názvem Divoká dráha domovio a je spojeno s prožitkem úzkosti. Nebo: „obklopen mrtvými / kteří jsou zapotřebí / světu." 15 Mezitím je několikrát řeč o těch drahých, kteří odešli: „V ulicích / sbírám do náruče / dávné drahé hlavy / které se po letech / a po dnech vytratily”16. „Už se netrápí / Mrtvý ted' patř́i jenom jí.”17 Dále: „Před týdnem / domov // Dnes se svítáním / za špičatou mř́ǐzí / samotný zelený hrob.”18 Dál: „Jsem doma tady? / Naposledy? // Jako by domovy / mohly být / poslední."19 A verše, které přivádějí v úžas: „Přicházíš živý / beze stop hlíny / uchovaný v mrtvých / kruzích let." ${ }^{20}$ Zde už se čtenář chvěje před hmatatelnou př́tomností tajemství. A je možné pokračovat: „Snadno jsou př́stupní / mrtví proti živým”"21 nebo: „Mým domkem na vinici / chodí živí i mrtví”22 až k onomu: „Ze zdí střeží mrtví / okamžik který bdís."”23 Ale nejsme ještě u konce knihy: „Ráno přicházejí / krátce mrtví / k posteli [...] bloudí pokoji / palčivou zimou / kterou nedokážeme obléct / ani skrýt" "24, „Tolik nám jich umřelo na očích [...] žalobná bolest / všechna úzkost a stesk / a odedávna naděje." ${ }^{25}$

Závěrečná část knihy je lyričtějšíi, impresivní. Ne že by byla imprese těžištěm zbylých básní, i zde proudí zástupy mrtvých, ale Viola Fischerová už vše vypověděla. Nyní chce zachytit, co zbývá: výseky děje, momentky, stesk a snad i melancholické přehlížení, jež vede k usebrání a modlitbě. Ty poslední básně jsou

\footnotetext{
${ }^{14}$ Ibidem, s. 9.

15 Ibidem, s. 14.

16 Ibidem, s. 12.

17 Ibidem, s. 15.

18 Ibidem, s. 37.

19 Ibidem, s. 39.

${ }^{20}$ Ibidem, s. 41.

${ }^{21}$ Ibidem, s. 43.

22 Ibidem, s. 62.

${ }^{23}$ Ibidem, s. 74.

24 Ibidem, s. 81.

25 Ibidem, s. 82.
} 
skutečně modlitbou, jíž předchází už ani ne vzpomínání, spíš jenom pohled a vnímání a dosazení vlastního osudu do těch torzovitých, neucelených a skrytých vzpomínek. Vlastně nahlížíme něčí sebeprojekci do vzpomínek, jež nám zůstaly nesvěřeny. A modlitba? Vždyt' ta je mimo jiné též projekcí či sebeprojekcí, co však víc, je téměř jediným prostředkem spojení s mrtvými. Ono společenství živých a mrtvých se udržuje skrze modlitbu.

Magická př́tomnost smrti je faktickým dokladem o nerozlišitelnosti a nerozdělitelnosti, o neodpoutatelné spojitosti života a smrti, zrození a zániku. Život a smrt jedno jsou! „Tehdy a ted’ je jedno / od mrtvého nás dělí dech / od chladného ne já / tenká plet,","26 (mrtví) ,budí dávnou ranní úzkost / ale nepřou se o to / jak být;"’27 „Jaký kruh / mi po léta brání / spatřit to odjinud / z té druhé odvrácené / tvojí strany;" ${ }^{28}$ „Marně naléhá na slova / nevěda že jen řeč živých / je ve dví // a jedna že mlčí / když mluví." ${ }^{29}$ Lépe tedy: život a smrt jsou dvě strany jednoho. A v poslední básni se vše završuje a poslední báseň je v každé předchozí př́itomna.

Celé básnické dílo Violy Fischerové vykazuje rysy nezáměrné kompozice. Básnířka dílo netvoří, dílo je prostřednictvím jejího života stvořeno. Nejvíce patrné je to ve vzájemné propojenosti a tematické specifičnosti posledních tří básnických sbírek: Předkonec, ${ }^{30}$ Písečné ditě, ${ }^{31}$ Domek na vinici ${ }^{32}$. První sbírce odpovídá téma smrti, kdy se vyrovnává s nemocí a umíráním vlastního bratra. Druhá kniha přináší zkušenost lásky, lásky neočekávané, odevzdané, okouzlující. Sbírku Domek na vinici lze charakterizovat jako reflexi vlastního života, stáŕí a blížící se smrti. Závěrečné tři knihy, výše naznačená tematická posloupnost, potvrzují osudovou sepjatost básnířčina života a díla. V tomto smyslu, aniž by tušil, jak se bude běh věcí prríštích odvíjet, učinil pregnantní poznámku v doslovu k básnické sbírce Předkonec literární historik a kritik Jaroslav Med:

Cestu k poezii jí neotevřel úžas nad skutečností, ale především a zejména touha „dovědět se, co se vlastně stalo, oč šlo". Nic není tedy v její tvorbě pouze básní, která by se sytila krásou tvaru a neobvyklostí metafor, ale každý její verš chce být skromnou rovnomocninou života, jenž byl prosycen nejen láskou, ale také bolestí a zklamáním. Proto je od počátku základním leitmotivem jejích veršů všudypřítomná symbióza lásky a utrpení uprostřed plynoucího času, který je stálým mementem básnířčiny výpovědi. A na konci uplynulého času na nás čeká „smrt ve vlastním těle” jako stálý otazník po smyslu všeho i vykřričník touhy po spáse a nesmrtelnosti. ${ }^{33}$

Kniha nese lapidární titul Předkonec, konec je až na věčnosti. Poezie, kterou přináší, je krutá svou deskriptivností. Viola Fischerová vede dialog s umírajícím
${ }^{26}$ Ibidem, s. 64.
27 Ibidem, s. 43.
${ }^{28}$ Ibidem, s. 33.
29 Ibidem, s. 31.
30 V. Fischerová, Předkonec, Praha 2007.
31 V. Fischerová, Písečné ditě, Praha 2007.
32 V. Fischerová, Domek na vinici, Praha 2009.
${ }^{33}$ V. Fischerová, Předkonec..., s. 73. 
bratrem, a tudíž dialog se smrtí, potažmo s vlastní smrtí. Konec života a blízkost smrti s sebou přináší vědění a z něj vyvěrající prosbu o odpuštění. Strach ze smrti se mísí stále častěji s odkazem na osud, o němž jsme ve štastných chvílích života nechtěli vědět. Osudovost zde zatím není dominantním rysem básnířcina vyjádření, daleko spíš vytváŕí prostor pro úvahy o naději: „Tolik kř́žǔu — / a nikde Kristus / tolik přibitých těl — a nikde kněz / Duše a duše na jazyku — a nikde nadějez." ${ }^{44}$ Celá kniha při vší své popisnosti nepostrádá dynamiku, je nikoliv exaltovaným, ale dramatickým záznamem smrti. Využívá všechny možné prostředky hledání odpovědi na otázku, co přináší smrt, co je obsaženo ve smrti a jak prožít smrt, jak přijmout zkušenost smrti. Toto hledání a sveřepá touha nahlédnout život z druhého břehu ovšem sama o sobě implikuje zkušenost smrti, jež by nakonec měla vést $\mathrm{k}$ vyrovnání a smíření. A tak přestože hovoří o bratrovi a $\mathrm{s}$ bratrem, o blízkých i vzdálených umírajících a zemřelých, hovoří především sama o sobě. Slovo „úzkost” se jí spojuje se slovem „lítost”. Přesto se zde objevuje vzpoura proti smrti, niterné bezprostřední vzepření se tomu, co ji čeká a nemine, minimálně jednou se objeví i sarkasmus, ale za vším se skrývá osud, třeba nepřiznaný nebo i jen prozatím nepřijatý. Závěrečnou část knihy bychom mohli označit jako tryznu za zemřelé. I proto získává poezie Violy Fischerové bilanční charakter a přiznaná, přijatá pravda, faktická skutečnost smrti, ji vede k jisté oproštěnosti, osvobození z poznání a k rozhodnutí být připraven přijmout vlastní smrt. Poslední tři básně knihy jsou impozantním vyjádřením takového postoje, jenž není možný bez vědomí smíření a odevzdanosti. Závěrečná skladba může mít stejně jako celé dílo autobiografické rysy, každopádně ona osobní odevzdanost je v ní transformována $\mathrm{v}$ prosbu a modlitbu: „Večer před Velkým pátkem / však děti sní / jak Tě vysvobodí z vězení // aby Tě nebili / jako koně / co upadl na dláždění // Pane dej jim / at' na louce v ráji / potkají toho koně / a taky ty psy // Rabboni." ${ }^{35}$

Sbírka Písečné dítě je nesena kontrastem mezi zrozenou a stvořenou láskou. Dokládají to první tři básně knihy. Málokdy se v lidském údělu, v údělu ženy, otevírá tak do široka rozevřená, téměř nepřekročitelná propast mezi životem a smrtí. Pokud si vzpomeneme na poslední báseň knihy Divoká dráha domovů, což v podstatě není báseň, ale přepis záznamu z náhrobku, na němž stojí, že matka zemřela ve stejný den, kdy se s ní jedno dítě, které již žilo, odebralo na věčnost, zatímco druhé přišlo na svět, vidíme, že to není jen kontrast života a smrti, ale že smrt — pokud přímo nepředbíhá život - jej provází někdy ve velmi krátkém sledu. Písečné ditě Viola Fischerová svým dotekem přivedla do života, dala mu tvářnost a sama byla přetvořena; její život dostal nový tvar, aniž by byl uzavřen, dotvořen. To činí jen stáří a smrt. V nanejvýš osobní básnické zpovědi jsou stáří a smrt neustále přítomny v doteku lásky. Ta proměna je životně důležitá na obě strany, umožňuje vyprosit si oproštěnost od minulosti a dává sílu a odhodlání k oběti? To je zřejmé, jakmile se do básnířčiných textů začne vkrádat další otázka: čím za to budeme platit!? Ale to

34 Ibidem, s. 26.

35 Ibidem, s. 72. 
je právě ono! Lásku si člověk nevybírá! Láska vede k pokoře! Okouzlení a moudrost nutně nemusí jít ruku v ruce, ale v tomto případě tomu tak je. Kdo nepoznal vysvobození láskou, nepoznal vysvobození moudrostí! „Božské dítě, které se na mne usmívá." ${ }^{36}$ Zázrak je být milován. Vyvolat z neproniknutelných hloubek tajemství zázrak zrození je aktem lásky, jenž není bez viny.

Kontrast lásky a smrti, spojení lásky a smrti, se pochopitelně odehrává na pozadí ubíhajícího času. Láska otevírá proměně a proměna se děje v čase a vždy stigmatizuje. Pozdní poezii Violy Fischerové nakonec vládne osud a čas. Obojí potvrzuje naléhavost a upř́mnost nečekané lásky a předpokládané blížící se ztráty, ztráty vlastního života naplněného láskou. I proto jsou zde frekventovány motivy úzkostného prožitku z dětství, vzájemnosti, odevzdanosti, starostlivosti, obětavosti. Vše završeno současnou zahrnující láskou, chápající, rozumějící, čekající, trpělivou. Motiv dětství se do veršů vkrádá neodbytně a jde ruku v ruce s intenzivním prožitkem stáríí; spojuje je i lidová píseň, kterou jsme v dětství slýchávali, ve stáří ji zpíváváme! Právě prožitek stáří se čas od času vyjeví jako marnost. Na jedné straně je vymezena pocitem opuštění, odloučení, čekání, úzkosti a zimy, jež sugeruje sestup do pekel, kdy duše spočívá na dně a chce mírit ke světlu, na druhé straně ji vymezuje velmi subtilní, jemná erotika stejně vlídná jako brunátná a naléhavě silná. „Vtiskni se do mne.” ${ }^{37}$ Láska, ale i vášeň, orgasmus, činí krásu. Přesto poetika, obrazivost básnických textů jsou tak přirozené a skromné, že z pravidla připadá na jednu báseň jen jeden obraz, který je korunou díla, nebo přirovnání, které odzbrojuje a pohladí. I v tom je láska. Viola Fischerová se vyjadřuje navýsost láskyplně a je to pro ni přirozené, jako snít v lásce: „,snila jsem, jako se dýchá.”38

Poslední sbírka, Domek na vinici, je, přísně vzato, odcházením. Viola Fischerová opět vede dialog, tentokrát s minulostí. Vrství vzpomínky, před očima jí vyvstává prošlý život, zpřítomnělá minulost snad v daleko výraznějších obrysech, než tomu bylo ve sbírce Předkonec. Vše minulé si vyvolává, a proto užívá apostrofy, formálního prostředku, kdy básník oslovuje nepř́tomné, vzdálené, ztracené, což ovšem koresponduje s odcházením a s nadějí na rozluštění hádanky života. Vyhledává a shromažd’uje bílá místa paměti, prázdná místa života, usiluje o dodatečné poznání dosud nepoznaného nebo jen tušeného, které nás dohání. V takovém ohlédnutí se daleko př́íř̌ji a naléhavěji vyjevují okamžiky míjení životů. Naléhavěji a konkrétněji se ohlašuje osudová danost života. Vše, co minulo, je zpř́itomněno v místech či věcech, jež zjevují život, co není. On vlastně je, ale jen v nás, kteři žijeme, a zemřelí nás — přítomni na místech prožitku lásky i bolesti — v našem srdci, chrání. Je tu pamět'. Nejen pamět' místa, ale pamět' života. Všechny tyto důsledně zpracované básnické reminiscence vyjadřují touhu po usmíření.

\footnotetext{
${ }^{36}$ V. Fischerová, Písečné ditě..., s. 21.

37 Ibidem, s. 48.

38 Ibidem, s. 55.
} 
Zde dominuje osud. Nabízí se srovnání s vnímáním osudu v řecké tragédii. Málokdy rozumíme tomu, co jsme udělali a co se děje; omlouváme se, činíme si výčitky, žádáme o odpuštění! Jsou to prosby. Ale nakonec nic nepomáhá, takže zbývá jen modlitba. Osud a jeho naplnění znamená v podání starých Řeků vyrovnání sil dobra a zla prostřednictvím našeho života. Aniž by to kde bylo explicitně řečeno, každý z lidí se rodí na tento svět jako obět'. Proč? Protože každý osud, jakékoli prokletí, může být vykoupeno jen obětí, a touto obětí je lidský život. Osud se nevztahuje jen na nás samotné, vztahuje se na celý svět, je tajemstvím v lůně země, je to něco jako dědičný hřích, princip život a smrti. Kromě Holana neznám $\mathrm{v}$ české literatuře tak krutou poezii!

Proto ty staré otázky: Proč se to stalo? Mělo se to stát? A mělo či muselo se to stát právě takto? Otázky bez odpovědí, jež nakonec uvozují zpytování svědomí a tíhu viny. At' už se Viola Fischerová ptá na prozřetelnost, osud nebo milosrdenství, v mnoha případech nachází místo odpovědi pusté prázdno. A tak zůstává konkrétní především stáří zasazené do neměnného rámce bytí. $Z$ něj na nás vyhlíží všudypřítomná smrt, smrt nikoli jako memento, ale jako exemplum zvýrazněné krátícím se časem. Každá událost vyvolává souvztažnost s myšlenkovým vzorcem. Dá se vyvolat osud? Ano. Jen zrozením. Závěr poslední básnické knihy Violy Fischerové je krutý a milosrdný zároveň. Jako předchozí básnické úvahy míří na dvě strany. Zaopatřit. Být zaopatřen. Nejde jen o její osud. Osudy druhých vnímá téměř jako věštka, jako Pythie. Je zlá? Ne, pouze pravdivá, proto Pythie. Etika s tím nemá co dělat, jako nemá etika co dělat se stářím a se smrtí. Je noblesní, kultivovaná, sveřepá, vše podstatné skryla. Jen málo úsměvu, jen málo ironie, jen málo bolesti; mnohá bolest v mnohém. Smích, katarze, to zašlo pro radost a lásku, intimitu nechala jen sobě. Poslední báseň knihy Domek na vinici zní: „Ubohá můra / křídla popel / a prach // Už hodiny sní / na bílé zdi / že dolétla do světla // jež nepálí." ${ }^{39}$

\section{Bibliografie}

Ariés P., Dějiny smrti (L'homme devant la mort, 1977), přel. D. Navrátilová, Praha 2000.

Assmann J., Smrt jako fenomén kulturni teorie. Obrazy smrti a zádušni kult ve starovékém Egyptě (Der Tod als Thema der Kulturtheorie. Todesbilder und Totenriten im Alten Ägypten, 2000), přel. R. Fialová, Praha 2003.

Corvisier A., Tance smrti (Les danses macabres, 1999), přel. L. Kolářová, Praha 2002.

Čep J., Rozptýlené paprsky, Praha 1991.

Davies D.J., Stručné dějiny smrti (A Brief History of Death, 2005), přel. M.F. Havrdová, Praha 2007.

Dionýsios Areopagita, O mystické teologii, O božských jménech (Мистическое богословие восточной церкви, 2001), přel. A. Černohous, Praha 2003.

Fischerová V., Divoká dráha domovů, Praha 1998.

Fischerová V., Domek na vinici, Praha 2009.

Fischerová V., Písečné dítě, Praha 2007.

${ }^{39}$ V. Fischerová, Domek..., s. 100. 
Fischerová V., Předkonec, Praha 2007.

Fischerová V., Zádušní básně za Pavla Buksu, Brno 1993.

Král P., Knihy o dobrém umíráni v českém prostredi ve druhé polovině 16. a prvni půli 17. století, [w:] Církev a smrt. Institucionalizace smrti v raném novověku, eds. M. Holý, J. Mikulec Praha 2007.

Landsberg P.L., Zkušenost smrti (Essai sur l'expérience de la mort, 1936), přel. L. Hejdánek, J. Sokol, Praha 1990.

Macho T., Smrt a truchleni v kulturologické perspektivě, přel. R. Fialová, [w:] J. Assmann, Smrt jako fenomén kulturni teorie. Obrazy smrti a zádušni kult ve starověkém Egyptě (Der Tod als Thema der Kulturtheorie. Todesbilder und Totenriten im Alten Ägypten, 2000), přel. R. Fialová, Praha 2003.

\section{Motives of old age and death in the later works by Viola Fischerová}

\section{Summary}

Old age is strictly connected with death. Death is not only the goal of human life. Death, as well as life, is its anthropological constant. This is essential for poetry of Viola Fischerová in its entirety, especially for last three collections Předkonec, Písečné ditěe, and Domek na vinici. In Fischerová's poetry, old age is synonymous with death. In his shadow life is revealed as fate. For most artistic representations of life, death is depicted as transience of the moment, in the form of memories stored in the memory. Deceased friends and loved ones are called out of memory in Fischerová's poetry to objectify her own old age and death that is aproaching.

Keywords: poetry, old age, death, fate, interpretation

\section{Motywy starości i śmierci w późnej twórczości Violi Fischerovej}

\section{Streszczenie}

Starość bezwarunkowo łączy się ze śmiercią, która nie jest jednak celem ludzkiego życia; śmierć, podobnie jak życie, jest jego stałą antropologiczną. I to właśnie stanowi podstawę poezji Violi Fischerovej w całej rozciągłości jej dzieła poetyckiego, przede wszystkim zaś trzech ostatnich tomików zatytułowanych: Předkonec, Pisečné ditě oraz Domek na vinici. Starość jest w ujęciu Fischerovej synonimem śmierci. W jej cieniu życie objawia się jako los. Za większością artystycznych ujęć śmierć stoi w postaci gwałtowności chwili, w postaci wspomnienia zapisanego w pamięci. Poezja Fischerovej wywołuje z pamięci zmarłych przyjaciół i bliskich, aby zobiektywizować starość i zbliżającą się śmierć.

Stowa kluczowe: poezja, starość, śmierć, los, interpretacja 